\title{
Institutionalising diasporic Islam: multiculturalism, secularism and the integration of Muslim immigrants in Britain
}

\section{Amika Wardana}

Faculty of Social Science, Yogyakarta State University and currently pursuing a PhD programme in Sociology at University of Essex, England

E-mail:a.wardana@uny.ac.idormasmicko@gmail.com

\begin{abstract}
The integration of Muslim immigrants in Western countries especially Britain has attracted wider attention both from academia, policymakers and public in general. Their different religion (i.e. Islam) has been regarded as the crucial factors in the process contextualised by the socio-political circumstances of the host society and the existence transnational link to the home country encouraging them to reproduce and transplant their ethno-religious tradition in diaspora. The article addresses the interplay between, on the one hand, the strong and weakness of the politics of multiculturalism and the secularisation and desecularisation of British society, and on the other, the institutionalisation of Islam in Britain amidst the persistent internal divisions and fragmentations of minority Muslim immigrant communities. As the result, Muslim immigrants have set up an ethno-religious integration trajectory through their own established socio-religious institutions and associations in parallel with the host country social and political ones. Integrasi imigran Muslim di negara-negara Barat khususnya Inggris telah memeroleh perhatian luas baik dari kalangan akademisi, pembuat kebijakan dan
\end{abstract}


publik pada umumnya. Keragaman agama mereka (termasuk Islam) dipandang sebagai faktor penting dalam proses yang dikontekstualisasi oleh lingkungan sosiopolitik masyarakat setempat dan hubungan transnasional yang ada dengan negara asal yang mendorong mereka mereproduksi dan mentransplantasi tradisi etnoreligi mereka di diaspora. Artikel ini memaparkan hubungan saling pengaruh antara kekuatan dan kelemahan politik multikulturalisme di satu sisi, dan institusionalisasi Islam di Inggris yang melahirkan pembagian dan fragmentasi internal di kalangan komunitas imigran Muslim minoritas di sisi lain. Akibatnya, imigran Muslim telah membangun peta integrasi etno-religi melalui lembagalembaga dan asosiasi-asosiasi sosio-religi mereka yang sudah mapan paralel dengan lembaga dan asosiasi social dan politik negara setempat.

\section{Keywords: Multiculturalism; Secularism; Muslims'integration; Diaspora}

\section{Introduction}

The study of the integration of immigrants with different religious backgrounds in Britain has focused on several ethno-religious groups such as the Sikhs, Hindus and, of concern in this study, Muslims. The integration of Muslim immigrants has attracted the interest of policymakers and researchers as they comprise the largest minority (immigrant) ethno-religious group in the country and because of the recently escalated global tension between the West and Islam. To note, though the presence of Muslim immigrants in Britain dates back to the seventeenth century, ${ }^{1}$ their number has begun to reach a 'critical mass' since the Second World War with the arrival of economic immigrants, refugees and asylum-seekers from ex-British colonies in the Indian subcontinent, East Africa and the Middle East. ${ }^{2}$ According to the 2011

${ }^{1}$ N. I. Matar, Islam in Britain 1558-1685, Cambridge: Cambridge University Press, 1998.

${ }^{2} \mathrm{H}$. Ansari, The Infidel Within: Muslim in Britain since 1800, London, Hurst and Company, 2004; S.Hussain, Muslims on the Map: A National Survey of Social Trends in Britain, London: Tauris Academic Studies, 2008. 
census, the number of Muslims in Britain has reached more than 2,7 millions or about $4,8 \%$ of the whole population. Their relatively higher birth rate and closely grouped under their similarity of Islamic faith despite the internal ethnic-racial differentiations have made them worthy enough for a further study.

The integration trajectory of Muslim immigrants in Britain constrained or enabled, on the one hand, by the politics of multiculturalism and secularisation of British society, and on the other, by their intention to pursue, adapt and reproduce their ethno-religious cultural traditions imported from and transnationally influenced by developments in the home country. I argue that integration is not a one way process in which immigrants adapt to the socio-cultural environment of the host society but that integration also involves the reproduction and adaptation of ethno-religious traditions brought from the home country into the diasporas. As a result, there exist multiple integration paths for immigrants who follow either the mainstream trajectory by incorporating into and adopting the secularised culture of British society or the ethno-religious one by reproducing their ethno-religious traditions and forming minority ethno-religious communities.

Importantly, the integration of Muslim immigrants in Britain has been contextualised, on the one hand, by transnational religious networks spawned in the home countries that bring in various ethno-religious traditions thus diversifying and fragmenting these minority religious communities. ${ }^{3}$ Recently, those transnational religious networks have also paved the way for more or less radical Islamist ideas that encourage disintegration and anti-Western sentiments within the Muslim immigrant

3P.Lewis, Islamic Britain: Religion, Politics and Identity among British Muslim: Bradford in the 1990s, London: I.B. Taurus, 1994; S.Gilliat-Ray, Muslims in Britain: An Introduction, Cambridge: Cambridge University Press, 2010. 
communities, especially among the youth. ${ }^{4}$ On the other hand, Muslim immigrants' integration has been also influenced by the prevalence of anti-Muslim hate sentiments or Islamophobia from the wider British society constructed from the Western Orientalist legacy and state and public securitisation of Islam especially after the World Trade Center terrorist attack in 2001 in New York and the London bombing in July 2005. ${ }^{5}$

However, having benefitted from British multiculturalism and the pragmatic religious tolerance and pluralism of British society, ${ }_{1}^{6}$ Muslim immigrants have successfully organised themselves, reproduced their ethnoreligious traditions and social institutions particularly after the arrival of the wives and children of Indo-Pakistani immigrants in the 1970s. ${ }^{7}$ Muslims have also been granted state and public recognition regarding their different ethno-religious traditions through, for example, exemptions from general rules such as dress codes and state funding for their ethno-religious associations and faith-based schools. ${ }^{8}$ These al-

${ }^{4}$ T.Abbas, "Introduction: Islamic Political Radicalism in Western Europe", in abbas, T. (ed.), Islamic Political Radicalism: A European Perspective, Edinbrugh: Edinbrugh University Press, 2007; J. Gest, Apart: Alienated and Eangaged Muslims in the West, London: Hurst and Co., 2010.

${ }^{5}$ Runnymede Trust, Islamophobia: a Challenge fo Us All, London: Runnymede Trust, 1997; T.Abbas, "British South Asian Muslims: before and after September 11", in Abbas, T. (ed.), Muslim Britain: Community Under Presure, London: Zed Books, 2005; C.Allen, "From Race to Religion: the New Face of Discrimination", in abbas, T. (ed.), Muslim Britain: Community Under Pressure, London: Zed Books, 2005; C. Allen, Islamophobia, Surrey: Burlington, Ashgate, 2010.

${ }^{6} \mathrm{C}$. Joppke, "Multiculturalism and Immigration: A Comparison of the United States, Germany, and Great Britain", Theory and Society, 25 (1996): 449-500; ; Kivisto, P. Multiculturalism in a Global Society. Oxford: Blackwell, 2002; Fetzer, J. S. \& Soper, J. C. Muslims and the State in Britain, France and Germany. Cambridge: Cambridge University Press, 2005; Modood, T. Multicultural Politics: Racism, Ethnicity and Muslims in Britain. Edinburgh: Edinburgh University Press, 2005.

${ }^{7} \mathrm{H}$. Ansari, The Infidel Within: Muslim in Britain since 1800. London, Hurst and Company, 2004; Hopkins, P. \& Gale, R. (eds.). Muslims in Britain: Race, Place and identities. Edinburgh: Edinburgh University Press, 2009; Gilliat-Ray, S. Muslims in Britain: An Introduction. Cambridge: Cambridge University Press, 2010.

${ }^{8} \mathrm{~N}$. Meer, Citizenship, Identity and the Politics of Multiculturalism: The Rise of Muslim Consciousness. Basingstoke: Palgrave Macmillan, 2010; Mcloughlin, S. N. \& Abbas, T., "United 
lowances have facilitated the emergence of an alternative ethno-religious integration trajectory for Muslim immigrants parallel to the mainstream integration path into secularised British society.

\section{British multiculturalism}

Multiculturalism has been inextricably linked to the public demands of immigrants (and ethnic or indigenous minorities) for the recognition of racial, cultural and religious differences and to the policy of democratic states to accommodate their peculiarities, grant them minority group rights and exempt them from certain legal or societal rules. ${ }^{9}$ The rubric of multiculturalism, though varied in terms of form and contents across different countries, has entailed a number of policies and legislation such as the inclusion of racial, ethnic or religious representation in public bodies and media, the adoption of multiculturalism in school curricula, exemption from dress codes, funding of ethnic or religious communal organisations and permission for the construction of places of worships for their different religion. ${ }^{10}$

In Britain, the politics of multiculturalism had begun to take to the fore with the arrival of non-White immigrants from former colonies (e.g. the Caribbean, the Indian subcontinent and East and West Africa) specifically to fill the labour shortage after the war and/or to seek asylum, avoiding prosecutions and conflict in their newly independent home countries. ${ }^{11}$ As Joppke (1996) described, the link between immi-

Kingdom", in Nielsen, J. S., AkgoNuL, S., Alibasicì, A., Mareichal, B. \& Moe, C. (eds.). Yearbook of Muslims in Europe. Leiden: Brill. 2010.

${ }^{9} \mathrm{C}$.Taylor, "The Politics of Multiculturalism", in Gutman, A. (ed.). Multiculturalism: Examining the Politics of Recognition. Princeton, New Jersey: Princeton University Press, 1994; Kymlicka, W. Multicultural Citizenship: A Liberal Theory of Minority Rights. Oxford: Oxford University Press, 1995.

${ }^{10} \mathrm{~K}$.Banting, \& Kymlicka, W. Multiculturalism and the Welfare State: Recognition and Redistribution in Contemporary Democracies. Oxford: Oxford University Press, 2006.

${ }^{11}$ Hesse, B., "Introduction: Un/Settled Multiculturalisms", in Hesse, B. (ed.) Un/Settled Multiculturalisms: Diasporas, Entanglements and Trasnruptions. London: Zed Book, 2000; Kivisto, P. Multiculturalism in a Global Society. Oxford: Blackwell, 2002. 
gration and the colonial legacy of the Empire is unique in British multiculturalism. Defined as 'subjects of the crown' under the 1948 British Nationality Act, immigrants from the new Commonwealth countries in the 1950s-1960s were granted British citizenship upon arrival, consequently enjoying social and political rights similarly to native White Britons. ${ }^{12}$ The colonial legacy of the British Empire - with its lack of effort to assimilate its subjects - was reconstituted in terms of the ways in which the British government treated and approached immigrants especially regarding their racial, ethnic and religious differences. As stated by the Home Secretary Roy Jenkins in his speech in May 1966, integration of immigrants is defined "not as a flattening process of assimilation but as equal opportunity, accompanied by cultural diversity, in an atmosphere of mutual tolerance".

Official British multiculturalism espouses legislation to recognise racial, ethnic, cultural and religious differences of immigrants and their offspring by granting them special treatment, exemptions, legal protection and by allowing them to make claims in the name of minority group rights. ${ }^{13}$ In short, British multiculturalism construes society not only as 'a community of citizens' but also as 'a community of communities'; ${ }^{14}$ such civic assimilation with an emphasis on recognising (minority) group rights as complementary to individual rights is grounded in liberal forms of citizenship. ${ }^{15}$

${ }^{12}$ T. Modood, "Introduction: the Politics of Multiculturalism in the New Europe", in Modood, T. \& Werbner, P. (eds.). The Politics of Multiculturalism in the New Europe: Racism, identity and Community, London: Zed Books, 1997.

${ }^{13} \mathrm{C}$. Joppke, "Multiculturalism and Immigration: A Comparison of the United States, Germany, and Great Britain", Theory and Society, 25 (1996): 449-500; Koopmans, R. \& Statham, P., "Challenging the Liberal Nation-State? Postnationalism, Multiculturalism, and the Collective Claims Making of Migrants and Ethnic Minorities in Britain and Germany", The Americal Journal of Sociology, 105 (1999): 652-696.

${ }^{14} \mathrm{~B}$. Parekh, Rethinking Multiculturalism, Basingstoke: Palgrave Macmillan, 2000, xv.

${ }^{15}$ P. Kivisto, Multiculturalism in a Global Society, Oxford: Blackwell, 2002; Modood, T. \& Kartoryano, R., "Secularism and the Accomodation of Muslim Identities", in Raymnod, G. G. \& 
Nevertheless, British multiculturalism has not been free from criticism and crisis from the outset. As Hesse (2000) points out, the policy is un-theorised, implying gaps between its normative ideas and empirical implementation in diverse social contexts with resultant 'unsettling' of established societal rules in British society (e.g. British national identity). Multiculturalism is accused of replacing the politics of anti-racism and racial discrimination that were traditionally regarded as the main challenges that non-White immigrants faced in terms of socio-economic and political marginalisation upon arrival in Britain. ${ }^{16}$ The emphasis on cultures (in plural) - informed by cultural pluralism or relativism and used as a justification for group rights to pursue different cultural traditions even if illiberal ones such as oppressing women ${ }^{17}-$ is considered to contradict the liberal philosophy of individual rights. ${ }^{18}$ Ultimately, the policy of multiculturalism was accused of limiting socio-economic integration of immigrants, creating social isolation or segregation in society and fostering radicalism, extremism and terrorism especially among Muslim youths. These conditions have ultimately discouraged the social cohesion of British society. ${ }^{19}$

This crisis led the British government (and other Western European governments too) to move away from using the term multiculturalism

Modood, T. (eds.). The Construction of Minority Identity in France and Britain, Basingstoke, Hampshire and New York: Palgrave Macmillan, 2007.

${ }^{16}$ F. Anthias \& Yuval-Davis, N. Racialized Boundaries: Race, Nation, Gender, Colour and Class and the Anti-racist Struggle, London, Routledge, 1993; Kundnani, A., "The Death of Multiculturalism", Race and Class, 43 (2002): 67-72.

${ }^{17} \mathrm{~F}$. Anthias, "Beyond Feminism and Multiculturalism: Locating Difference and the Politics of Location", Women's Studies International Forum, 25, (2002): 275-286.

${ }^{18} \mathrm{~B}$. Barry, Culture and Equality: An Egalitarian Critique of Multiculturalism, Cambridge: Polity, 2001; Joppke, C. \& Luke, S., "Introduction: Multicultural Questions", in Joppke, C. \& Luke, S. (eds.). Multicultural Questions, Oxford: Oxford University Press, 2002.

${ }^{19} \mathrm{~S}$. Vertovec \& Wassendorf, S., "Introduction: Assessing the Backlash against Multiculturalism in Europe", in Vertovec, S. \& Wassendorf, S. (eds.) The Multiculturalism Backlash: European Discourses, Policies and Practices, London: Routldge, 2010. 
in policies concerning the integration of (non-White) immigrants. The new political disposition was expressed clearly in a speech on radicalisation and Islamic extremism by the British Prime Minister, David Cameron, delivered at the Munich Security Conference (05/02/2011). To encourage further integration of immigrants, the British government has initiated policies to promote British nation building and belonging, common values and national identity instead of encouraging immigrants to pursue their different cultural traditions. The increased governmental emphasis upon 'national integration and social cohesion' addressed particularly to immigrants is noted by some scholars as a return to assimilation. ${ }^{20}$

Notwithstanding the reluctance to use the term multiculturalism in current British government policy, ${ }^{21}$ the multicultural mode of immigrant integration is not easily extinguished or replaced by other political projects such as the former assimilation mode. ${ }^{22}$ The political change in the British state (and other Western states) to cease using the term multiculturalism is not a 'seismic shift ${ }^{23}$ or a political U-turn favouring an integrationist policy for immigrants, yet rather 'a civic re-balancing'24 through re-affirmation of British national values (e.g. law obedience, mutual tolerance, respect for equal rights) while maintaining positive racial, ethnic and religious monitoring to ensure public acceptance and prevent direct or indirect discrimination towards minorities. The term multiculturalism has been replaced with a new term 'diversity' alongside

\footnotetext{
${ }^{20}$ L. Back, Keith, M., Khan, A., Shukra, K. \& Solomos, J. New labour's White Heart, "Politics of Multiculturalism and the Return of Assimilation", the Political Quaterly, 73 (2002a): 445-454.

${ }^{21}$ S. Vertovec \& Wassendorf, S., "Introduction: Assessing the Backlash against Multiculturalism in Europe", in Vertovec, S. \& Wassendorf, S. (eds.) The Multiculturalism Backlash: European Discourses, Policies and Practices, London: Routldge, 2010.

${ }^{22}$ P. Kivisto \& Faist, T. Citizenship: Discourse, Theory, and Transnational Prospects, London: Blackwell, 2007.

${ }^{23} \mathrm{C}$. Joppke, "The Retreat Of Multiculturalism in The Liberal State: Theory And Policy", The British Journal of Sociology, 55 (2004): 249.

${ }^{24} \mathrm{~N}$. Meer \& Modood, T., "The Multicultural State We're In: Muslims, 'Multiculture' and the 'Civic Re-balancing' of British Multiculturalism", Political Studies, 57 (2009): 483.
} 
equality as a mode of socio-economic and political incorporation of immigrants. ${ }^{25}$

\section{Secularisation and desecularisation in British society}

Britain is currently perceived as a secular country, though its cultures and social institutions have been founded under the auspices of Christianity. ${ }^{26}$ It is believed that Christianity shaped the popular cultural understanding of 'Britishness' over several centuries. Informed by the secularisation thesis, however, the rapid phase of industrialisation in the nineteenth century then followed by modernisation and social differentiation have turned British people away from religion in the twentieth century. The declining role of religion, specifically the Christian church in British politics and the public sphere - as its societal and political functions were replaced by state apparatuses - has also impacted on the decreasing religious commitments of the masses (e.g. church membership, churchgoing). ${ }^{27}$ In a nutshell, religion has had a relatively limited role in modern British society.

Secularisation in Britain accelerated from the 1960s onwards stimulated by certain political and societal changes in modern British society. ${ }^{28}$ The establishment of the welfare state after the war had pushed the

${ }^{25}$ T. Faist, "Diversity - a new mode of incorporation?", Ethnic and Racial Studies, 32 (2009): 171-90; ; Vertovec, S. \& Wassendorf, S., "Introduction: Assessing the Backlash against Multiculturalism in Europe", in Vertovec, S. \& Wassendorf, S. (eds.) The Multiculturalism Backlash: European Discourses, Policies and Practices, London: Routldge, 2010.

${ }^{26} \mathrm{C}$. G. Brown, Religion and Society in Twentieth-Century Britain. Harlow: Pearson Education Limited, 2006; Woodhead, L., "Introduction", in Woodhead, L. \& Catto, R. (eds.). Religion and Change in Modern Britain, Abingdon: Routledge, 2012.

${ }^{27}$ S. Bruce, God is Dead: Secularization in the West. Oxford: Blackwell, 2002; Bruce, S. Secularization: In Defence of Unfashionable Theory, Oxford: Oxford University Press, 2011.

${ }^{28} \mathrm{C}$. G. Brown, Religion and Society in Twentieth-Century Britain, Harlow: Pearson Education Limited, 2006; Mcleod, H. The Religious Crisis of the 1960s, Oxford: Oxford University Press, 2007; Green, S. J. D. The Passing of Protestant England: Secularisation and Social Change c. 1920-1960, Cambridge: Cambridge University Press, 2011. 
Church to surrender its prominent social roles to the state, especially in health services, education and welfare programmes. ${ }^{29}$ These changes have ultimately diminished the Church's societal influence over preserving the Christian religiosity of the masses and nurturing Christian faith among the youth. ${ }^{30}$ Importantly, the flourishing of pop culture (through music, television and other media) triggered women's emancipation (such as resistance to traditional female religious roles in the family), a sea change in sexual attitudes (such as the acceptance of premarital and extramarital sex) and attitudes towards marriage (such as a preference for cohabitation and the recognition of gay and lesbian marriages). ${ }^{31}$ These changes signify a disestablishment of institutional structures based on cultural traditionalism and socio-political religious authority as grounded in Christian values of the Anglican Church in Britain. ${ }^{32}$ Ongoing secularisation in Britain is evident in statistical data describing declining numbers of people affiliated to religion, of church membership, churchgoers, babies being baptised, children attending Sunday schools and marriages solemnised in the Christian tradition. ${ }^{33}$

However, the religious life of British people is not as clear-cut but is more nuanced with ambiguities and contradictions and is influenced by multilayered social and political structures. Popularly termed 'believing

${ }^{29}$ S. Johnsen, "Case Study 6: the Role of Faith-based Organization in service provision for homeless people", in Woodhead, L. \& Catto, R. (eds.). Religion and Change in Modern Britain, Abingdon: Routledge, 2012.

${ }^{30}$ L. Woodhead, "Introduction", in Woodhead, L. \& Catto, R. (eds.). Religion and Change in Modern Britain,Abingdon: Routledge, 2012.

${ }^{31} \mathrm{C}$. G. Brown, The Death of Christian Britain: Understanding secularisation 1800-2000, Oxon: Routledge, 2009.

${ }^{32}$ H.Mcleod, The Religious Crisis of the 1960s, Oxford: Oxford University Press, 2007.

${ }^{33}$ S.Bruce, Secularization: In Defence of Unfashionable Theory. Oxford: Oxford University Press, 2011; Voas, D. \& Crockett, A., "Religion in Britain: Neither Believing nor Belonging", Sociology, 39 (2005): 11-28. 
without belonging', Davie ${ }^{34}$ argues persuasively that while people have ceased to follow religious rules and to submit to institutional churches, their beliefs in the existence of God and the afterlife have persisted, though are now manifested in diverse, more individualised, undisciplined and heterogeneous forms. As shown by the emergence of 'alternative spiritualities' since the 1970s - such as New Ageism, paganism and Mind-Body-Spirit - alternative beliefs have stood out not only against the rigid and dogmatic characteristics of religion but also as an alternative to agnosticism or atheism. ${ }^{35}$

The continuation of religious belief (and practice) is also illustrated by the phenomenon of 'vicarious religion', ${ }^{36}$ defined as "the notion of religion performed by an active minority but on behalf of a much larger number, who (implicitly at least) not only understand, but, quite clearly, approve of what the minority is doing". In other words, while the majority of the population have been secularised or become indifferent to (institutionalised) religion, they have sanctioned or even supported minority church leaders and churchgoers in maintaining (Christian) belief and in performing rituals on behalf of the nation.

An important factor countering secularisation in Britain is the enmeshment of religion and state, particularly in the case of the Church of England, established as the official religious body. Morris (2009) argues that the foundation of Great Britain as a Christian country, in which political and religious life was once inseparable, has not been

${ }^{34}$ G. Davie, "Religion in Modern Britain: Changing Sociological Assumptions", Sociology, 34 (2000): 113-28; Davie, G. Religion in Britain since 1945: Believing Without Belonging, Oxford: Blackwel, 1994.

${ }^{35}$ P.Heelas, "The Spiritual Revolution: From 'Religion' to 'Spritituality'" in Woodhead, L., Fletcher, P., Kawanami, H. \& Smith, D. (eds.), Religions in the modern World: Traditions and Transformations, London, New York: Routledge, 2002; Heelas, P. \& Woodhead, L. The Spiritual Revolution: Why Religion is Giving Way to Spirituality, London: John Wiley and Son, 2005.

${ }^{36} \mathrm{G}$. Davie, "Vicarious Religion: A Methodological Challenge", in Ammerman, N. T. (ed.). Eeveryday Religion: Observing Modern Religious Lives, Oxford: Oxford University Press, 2007, 22. 
easily swept away by the wind of secularisation. The preserved legacies of the public role of religion have (re-)emerged in forms of voluntary social welfare services organised by faith-based organisations. ${ }^{37}$ The crisis of the welfare state in the 1970s-1980s had opened the doors for non-government actors to actively participate in these projects. Recently, the government project to revitalise the voluntary welfare services, so-called 'The Big Society', is apparently giving more opportunities for faith bodies to maintain their public roles through providing and delivering social welfare services. ${ }^{38}$

Lastly, the arrival of immigrants from former British colonies since the 1950s has brought different Christian traditions as well as different religions particularly Islam and Hinduism. ${ }^{39}$ Brown (2006) notes that not only are these immigrants relatively immune from the societal and individual secularisation process of British society, but they and their offspring are showing more religious enthusiasm. Having benefitted from the official British policy of multiculturalism, non-Christian immigrants have enjoyed greater opportunities to pursue their different religious traditions and build their own houses of worships (e.g. mosques, temples and gurdwaras) and establish national bodies to represent them to the general public and to the state (e.g. the Muslim Council of Britain or Hindu Council UK). ${ }^{40}$ Suffice to say, the current configuration

${ }^{37}$ A. Dinham \& Lowndes, V., "Faith and the Public Realm", in Dinham, A., Furbey, R. \& Lowndes, V. (eds.). Faith in the Public Realm: Controversies, Policies and Practices, Bristol: The Policy Press, 2009.

${ }^{38}$ A. Dinham \& Jackson, R., "Religion, Welfare and Education", in Woodhead, L. \& Catto, R. (eds.). Religion and Change in Modern Britain, Abingdon: Routledge, 2012.

${ }^{39} \mathrm{C}$.Peach, "The United Kingdom: A major transfromation of the religious landscape", in Knippenberg, H. (ed.). The Changing Religious Landscape of Europe. Amsterdam: Het Spinhuis, 2005b; Woodhead, L., "Introduction", in Woodhead, L. \& Catto, R. (eds.), Religion and Change in Modern Britain, Abingdon: Routledge, 2012.

${ }^{40}$ R. Bluck, Gilliat-Ray, S., Graham, D. J., Singh, G. \& Zavos, J. Judaism, Sikhism, "Islam, Hinduism and Buddhism: post-war settlements", in Woodhead, L. \& Catto, R. (eds.), Religion and Change in Modern Britain, Abingdon: Routledge, 2012. 
of British society is not only overwhelmed by the ongoing secularisation and transformation of Christian faith and tradition but also by the diversification of non-Christian religious traditions that are alive, revitalising and ultimately changing Britain into a multifaith society. ${ }^{41}$

The main consequences of this new religious landscape revolve around the quest for wider acceptance in the secularised British public sphere and in the legislation and policies of the state. ${ }^{42}$ To note, these ethnic and religious minorities have begun to assert their religious differences while demanding similar rights traditionally enjoyed by Christian groups. Importantly, instead of rivalry and competition, these different religious groups tend to coalesce against the prevalence of secularisation in British society. ${ }^{43}$ The foundation of the Inter Faith Network in 1987 (consisting of national representative bodies of the major faith communities), followed by the foundation of other bilateral interfaith organisations (e.g. the Christian-Muslim Forum, the Hindu-Christian Forum) has encouraged good mutual relations between different faith groups as well as a single framework for engagement with the British government on religious policies. ${ }^{44}$

\section{The Muslim population of Britain: a socio-demographic profile}

The Muslim community has become the largest minority religious group in the UK. Their presence predates to the nineteenth century when a small number of Muslim traders, seafarers and seamen from the Middle

${ }^{41} \mathrm{C}$. G. Brown, Religion and Society in Twentieth-Century Britain. Harlow: Pearson Education Limited, 2006; Woodhead, L., "Introduction", in Woodhead, L. \& Catto, R. (eds.), Religion and Change in Modern Britain, Abingdon: Routledge, 2012.

${ }^{42}$ B.Parekh, Rethinking Multiculturalism, Basingstoke: Palgrave Macmillan, 2000.

${ }^{43}$ G. Ganiel \& Jones, P., "Religion, Politics and Law", in Woodhead, L. \& Catto, R. (eds.), Religion and Change in Modern Britain,Abingdon: Routledge, 2012.

${ }^{44}$ B.Pearce, "Case Study 2: the Inter Faith Network and the Development of Inter Faith Relation in Britain", in Woodhead, L. \& Catto, R. (eds.) Religion and Change in Modern Britain, Abingdon: Routledge, 2012. 
East, East Africa, the Indian subcontinent and the Malay Peninsula had been settling around port cities like South Shields, Cardiff and Liverpool. ${ }^{45}$ The Muslim population, however, began to grow after the Second World War with the influx of labour immigrants, refugees, asylum-seekers and professionals from diverse Muslim countries. ${ }^{46}$ Hussain ${ }^{47}$ describes three general phases of the immigration stream, (i) from 1945 to the 1970 s they were predominantly young male labour immigrants largely from the Indian subcontinent to fill the labour shortages in London, the Midlands and other Northern cities; (ii) the 1970s to 1990s was characterised by family reunions with wives and children joining husbands who arrived in the previous phase; and (iii) from the 1990s onwards settlers have been predominantly asylum-seekers and refugees escaping from wars, conflicts and prosecutions in their home countries such as Bosnia, Afghanistan, Iran, Turkish-Cyprus and Somali. As a result, the Muslim population is characterised by its ethnic diversity, varied immigration motives and by having various religious sectarian affiliations brought from the home country into Britain. ${ }^{48}$

According to the 2011 census, the Muslim population in England and Wales consists of 2.7 million people or $4.8 \%$ of the population, two thirds higher than the previous 2001 figure of 1.6 million or $2.7 \%$ of the population (ONS, 2012). Unfortunately, the data has not yet been broken down to show detailed information in terms of ethnic diversity and regional distribution. However, according to the 2001 census, of

${ }^{45}$ F. Halliday, Britain's first Muslims: portrait of an Arab community. London: IB. Tauris, 2010; Ansari, H. The Infidel Within: Muslim in Britain since 1800, London, Hurst and Company, 2004.

${ }^{46}$. S. Nielsen, Muslims in western Europe. Edinburgh: Edinburgh University Press, 2004; Peach, C., "The United Kingdom: A major transfromation of the religious landscape", in Knippenberg, H. (ed.), The Changing Religious Landscape of Europe, Amsterdam: Het Spinhuis, 2005b.

${ }^{47}$ S. Hussain, Muslims on the Map: A National Survey of Social Trends in Britain, London: Tauris Academic Studies, 2008, 24-5.

${ }^{48}$ S.Gilliat-Ray, Muslims in Britain: An Introduction, Cambridge: Cambridge University Press, 2010. 
the whole Muslim population, $68 \%$ are of South Asian origins as Pakistanis account for $43 \%$ alone, representing the largest and most dominant ethnic group. Bangladeshis make up $17 \%$ of the population leaving Indian Muslims with less than $9 \%$. White Muslims contribute about $11.6 \%$ consisting of a small number of White British converts along with immigrants and refugees from Eastern Europe (e.g. Bosnia) and the Middle East. Other Asian ethnic groups (e.g. Indonesians, Malaysians), Black (e.g. Somalis) and Chinese Muslims account for 5.8\%, $6.9 \%$ and $3.7 \%$ respectively. ${ }^{49}$

Peach (2005a) points out the rapid growth of the Muslim population from about 21,000 in 1951 to 55,000 in 1961 , reaching 250,000 in 1971 , nearly 600,000 in 1981, a million in 1991, 1.6 million in 2001 and 2.7 million in $2011 . .^{50}$ The most recent figures for Muslim population growth is confirmed by the 2009 Labour Force Survey in which the Muslim population had grown by more than 500,000 in the four years between 2004 and 2008. ${ }^{51}$ The 2010 Pew report on Muslim religious networks in Western Europe (The Pew Forum, 2011) also estimates a similar figure stating an increase of $74 \%$ to 2.9 million Muslims living in Britain. The dramatic rise of the Muslim population in the last few decades can been explained by the fact that the majority of them are demographically 'young', aged 20 to 30 and tend to marry early, resulting a higher fertility rate compared to the wider population; and by

${ }^{49}$ Ons. Census 2001: Key Statistics for Local Authorities in England and Wales, 2003; see also Peach, C., "Britian's Muslim Population: an Overview", in Abbas, T. (ed.), Muslim Britian: Coomunity Under Presure, London: Zed Books, 2005a; Hussain, S. Muslims on the Map: A National Survey of Social Trends in Britain, London: Tauris Academic Studies, 2008.

${ }^{50} \mathrm{H}$. Ansari, The Infidel Within: Muslim in Britain since 1800. London, Hurst and Company, 2004; Ons. Religion in England and Wales 2012. Available: http://www.ons.gov.uk/ons/rel/ census/2011-census/key-statistics-for-local-authorities-in-england-and-wales/rpt-religion.html.

${ }^{51} \mathrm{R}$. Kerbaj, "Muslim population 'rising 10 times faster than rest of society'", Times Online, 2009. 
the steady stream of immigration and a willingness within Muslim communities to report religion in the census. ${ }^{52}$

The crucial socio-demographic profile of the Muslim population, particularly the majority with South Asian origins, revolves around general deprivation contingent upon economic disadvantages, lower educational attainment, limited skills and lack of prospects for professional employment. ${ }^{53}$ Deprivation among Muslims is linked to the relative lateness of their arrival - especially Bangladeshis - at times when the British economy has been declining and the prevalence of Islamophobia has hindered their job prospects. ${ }^{54}$ Another factor includes the strong patriarchal ethno-Islamic tradition of (South Asian) Muslim families (e.g. the family honour of Purdah) that prevents women taking public roles particularly in formal employment and other economic activities (Brown, 2000). Their deprived condition is further combined with the underperformance of (South Asian) Muslim youths in schools. ${ }^{55}$

The majority of Muslim immigrants and their offspring have resided in the geographically concentrated urban areas of industrial cities shaped by a chain of migration to fill labour shortages in the initial period. ${ }^{56}$ According to the 2001 census (ONS, 2003), London is considered to have the largest number and the most ethnically diverse Muslim inhabitants with about 607,000, in which Bangladeshis make up the largest

${ }^{52} \mathrm{C}$. Peach, "Britian's Muslim Population: an Overview", in Abbas, T. (ed.), Muslim Britian: Coomunity Under Presure, London: Zed Books, 2005a; Hussain, S. Muslims on the Map: A National Survey of Social Trends in Britain, London: Tauris Academic Studies, 2008; Gilliat-Ray, S. Muslims in Britain: An Introduction, Cambridge: Cambridge University Press, 2010.

${ }^{53} \mathrm{~T}$. Modood, "Introduction: the Politics of Multiculturalism in the New Europe", in Modood, T. \& Werbner, P. (eds.), The Politics of Multiculturalism in the New Europe: Racism, identity and Community, London: Zed Books, 1997.

${ }^{54}$ Runnymede Trust, 1997.

${ }^{55}$ T. Abbas, "British South Asian Muslims: before and after September 11", in Abbas, T. (ed.). Muslim Britain: Community Under Presure, London: Zed Books, 2005.

56Z. Dahya, "The Nature of Pakistani Ethnicity in Industrial Cities in Britain", in Cohen, A. (ed.) Urban Ethnicity, London: Tavistock, 1975. 
group. The rest are mainly concentrated in Birmingham (192,000), Greater Manchester $(125,000)$ and West Yorkshire (Bradford and Leeds, $150,000)$. In these cities, the Muslim population is largely dominated by those of Pakistani origin, for example, $60 \%$ in Greater Manchester and $70 \%$ in the West Midlands. ${ }^{57}$ Additionally, as Muslim immigrants tend to live in close proximity, certain local authorities like Tower Hamlets and Newham in London have a very high number of Muslim inhabitants. ${ }^{58}$

As mentioned previously, the geographic concentration of the Muslim population has become a public concern in terms of the preference among Muslims for (self-) segregation and pursuing a 'parallel life' separated from and ultimately threatening the social cohesion of British society. ${ }^{59}$ This is partly linked to the 2001 riots between Indo-Pakistani Muslim youths and the Police in northern English cities. ${ }^{60}$ Philips $^{61}$ argues that the Muslims' self-segregation could be understood positively as a strategy to survive economically, to preserve their ethno-religious traditions for later generations in a considerably secular environment and to avoid forms of racism and harassment in 'White' areas. However, Muslim immigrants, particularly the second generation, have established various (ethno-)religious associations that actively engage in British social, political and economic life. ${ }^{62}$ Suffice to say, Muslim immi-

\footnotetext{
${ }^{57}$ S. Hussain, Muslims on the Map: A National Survey of Social Trends in Britain, London: Tauris Academic Studies, 2008.

${ }^{58}$ S. Gilliat-Ray, Muslims in Britain: An Introduction, Cambridge: Cambridge University Press, 2010, 119.

${ }^{59}$ T. Cantle, Community Cohesion: A Report of the Independent Review Team,London: HMSO, 2001.

${ }^{60}$ P. Bagguley, \& Hussain, Y. Riotous Citizens: Ethnic Conflict in Multicultural Britain, London, Ashgate, 2008.

${ }^{61}$ D. Philips, "Parallel lives? Challenging discourses of British Muslim self-segregation", Environment and Planning Deevelopment, 24 (2006): 25-40.

${ }^{62}$ P. Lewis, Islamic Britain: Religion, Politics and Identity among British Muslim: Bradford in the 1990s, London: I.B. Taurus, 1994; Hopkins, P. \& Gale, R. (eds.). Muslims in Britain: Race, Place and identities, Edinburgh: Edinburgh University Press, 2009, just to name a few.
} 
grants are to an extent still in the process of integrating into British society.

\section{Unity, diversity and fragmentation of the British Muslim community}

The dominant public image of the Muslim community in the West is inextricably linked to the ethnic and national backgrounds of the majority Muslim immigrant population in each country. While the Arabo-Moroccan and Turkish immigrants and their offspring are more visible both in France and Germany respectively, the profile of Indo-Pakistani immigrants has dominated the public discourse of the Muslim community in Britain. ${ }^{63}$ The British Muslim community is constructed differently within two discursive cultural domains: the external, public domain and the internal demotic one. ${ }^{64}$ The dominant discourse refers to the existing tendency in British society to see minority immigrants on the basis of tacit categorisation of race, ethnicity or religion. Muslim immigrants, irrespective of their internal ethnic or sectarian differences and religiousness (or lack of), tend to be understood as a homogenous religious community with a particular reference to Indo-Pakistani Muslims that compose the majority population. ${ }^{65}$

The internal demotic discourse refers to the fact that Muslim communities, perceived as if a unified religious group, are shaped by persisting internal diversity and fragmentation primarily on the basis of different primordial ethnic affinities and religious sectarian affiliations. To a certain degree, nonetheless, the unity of Muslims as grounded in the

${ }^{63}$ S. Vertovec \& Peach, C. (eds.). Islam in Europe: The Politics of Religion and Community, Basingstoke: Macmillan, 1997; Nielsen, J. S. Muslims in western Europe. Edinburgh: Edinburgh University Press, 2004; Fetzer, J. S. \& Soper, J. C. Muslims and the State in Britain, France and Germany, Cambridge: Cambridge University Press, 2005.

${ }^{64}$ G.Baumann, Contesting Culture: Discourse of identity in multi-ethnic London, Cambridge: Cambridge University Press, 1996.

65]. S. Nielsen, Muslims in western Europe, Edinburgh: Edinburgh University Press, 2004. 
normative concept of the Ummah has been re-contextualised and reconstituted in diaspora. The Muslim diaspora in the West, if we can use the term, is more or less a new phenomenon for Muslims, in which Muslim immigrants coming from diverse religious or non-religious cultural traditions, national backgrounds and having diverse motives for immigration have lived side by side as a minority religious community in non-traditionalist Muslim lands. ${ }^{66}$ Moghissi et. al. ${ }^{67}$ argued cogently that the Muslim diaspora should not be construed as the sole reification of the Ummah that was forged through the shared unity of the Islamic faith and of the religious commonalities amongst Muslim immigrants but, importantly, as a reification of their "collective consciousness about group members' marginal location in the larger society in which they reside".68

The prevalence of anti-Islam or anti-Muslim hate sentiments named Islamophobia ${ }^{69}$, the securitisation of Islam after the World Trade Center terrorist attack in 2001, the US-led invasion of Afghanistan and Iraq and the London bombings in July $2005^{70}$ have politicised the presence of all immigrants with Muslim heritages. Notably, there has been a shift in the British public conception of racial minorities targeted for discrimi-

${ }^{66}$ ]. L. Esposito, "The Muslim Diaspora and the Islamic World", in Hunter, S. T. (ed.). Islam Europe's Second Religion: The New Social, Cultural and Political Landscape,London: Praeger, 2002; Dasetto, F., "Muslims in Western Europe: Sociohistorical Developments and Trends", in Tsugitaka, S. (ed.), Muslim Societies: Historical and Comparative Aspects, London: RoutledgeCurzon, 2004.

${ }^{67} \mathrm{H}$. Moghissi, Rahnema, S. \& Goodman, M. J. Diaspora by Design: Muslim Immigrants in Canada and Beyond, Torronto, Buffalo, London: The University of Torronto Press, 2009, 11.

${ }^{68} \mathrm{H}$. Moghissi, (ed.), Muslim Diaspora: Gender, culture and identity. Oxon: Routledge, 2006; Moghissi, H., "Introduction", in Moghissi, H. (ed.), Muslim Diaspora in the West: Negotiating Gender, Home and Belonging, Farnham: Ashgate, 2010.

${ }^{69}$ Islamophobia is defined as "unfounded hostility toward Islam ... refer[ing] to the practical consequences of such hostility in unfair discrimination against Muslim individuals and communities, and the exclusion of Muslims from mainstream political and social affairs" (Runnymede Trust, 1997: 4).

70]. Cesari, Securitisation of Islam in Europe. In: CESARI, J. (ed.) Muslims in the West after 9/11: Religion, Politics and Law, Oxon: Routledge 2010. 
nation from 'colour' in the 1950s-1960s, 'race' in the 1960s-1980s, 'ethnicity' in 1990s; to 'religion' (especially Islam) in the present time. ${ }^{71}$ Islamophobia denotes a 'closed view' on Islam - similar to the classic orientalist viewpoint - as a monolithic and static religious value system, aggressive towards the West and presenting a real threat to society (Allen, 2010) ${ }^{72}$. Living under these hostile circumstances, Muslims, regardless of their level of religiousness (or lack of), different sectarian affiliations, loyalties and affinities to their ethno-religious communities, have suffered with the same pain or sense of victimhood ${ }^{73}$ and the label of Muslim has (wittingly or not) come to the forefront of their socio-political identity marker. ${ }^{74}$

Furthermore, the existence of what Grillo75 described as "an imagined coalescence of peoples of different origin and background under

\footnotetext{
${ }^{71}$ Recent studies reveal the rise of anti-Muslim hate sentiments within British society, see C. Allen, Islamophobia, Surrey, Burlington, Ashgate, 2010.

The aggressive anti-Islam/Muslim campaign initiated by the British National Party and later continued by the newly founded group, the English Defence League has helped to spread this form of xenophobia, see J. Gest, Apart: Alienated and Eangaged Muslims in the West, London: Hurst and Co., 2010.

The tendency within the British media to portray Islam/Muslims as a threat to Western secular/liberal democracy has also supported this xenophobia in/directly.

${ }^{72}$ Allen (2010) argues that the authoritative Runnymede Trust's definition of 'Islamophobia' has influenced discourse by examining anti-Islam/Muslim attitudes through the varied criticisms from different groups in society including from Muslim groups and by failing to differentiate it from other similar forms of discrimination and xenophobia based on race, ethnicity and so on. See $C$. Allen, Islamophobia. Surrey, Burlington, Ashgate, 2010; Allen, C., "From Race to Religion: the New Face of Discrimination", in abbas, T. (ed.). Muslim Britain: Community Under Pressure, London: Zed Books, 2005; Grillo, R., "British and others: Fron 'Race' to 'Faith'", in Vertovec, S. \& Wassendorf, S. (eds.), The Multiculturalism Backlash: European Discourses, Policies and Practices, London: Routledge, 2010.

${ }^{73}$ A. S. Ahmed, Islam Under Siege, Cambridge, Polity Press, 2003; Abbas, T., "British South Asian Muslims: before and after September 11", in Abbas, T. (ed.). Muslim Britain: Community Under Presure, London: Zed Books, 2005.

${ }^{74}$ T.Modood, "Introduction: the Politics of Multiculturalism in the New Europe", in Modood, T. \& Werbner, P. (eds.), The Politics of Multiculturalism in the New Europe: Racism, identity and Community, London: Zed Books, 1997; Jacobson, J. Islam in Transition: Religion and Identity among British Pakistani Youth, London: Routledge, 1998.

${ }^{75}$ R. Grillo, "Islam and Transnationalism", Journal of Ethnic and Migration Studies, 30 (2004): 865.
} 
the heading Muslim" is more or less correlated with the role and the politicisation of religion within immigrant communities. This development works in two ways. Firstly, immigrants with or without their consent have been represented by the established Islamic socio-religious institutions and organisations to the state and the public in the receiving countries as if a bounded trans-ethnic minority religious community. Secondly, through those Islamic institutions and organisations, Muslim religious and community leaders have exercised ethno-religious influences over the immigrant populace espousing unity, brotherhood, sisterhood, solidarity and the collective socio-political identity of Muslims. The unity of Muslim immigrants is also testament to the rise of virtual transnational Islamic networks that allow Muslim immigrants to share information, religious materials and experiences with fellow co-religionists both in diaspora and worldwide. ${ }^{76}$

Nevertheless, the coalescence of Muslims in diaspora either shaped by their shared marginal positions or mobilised by Muslim religious community leaders is of course not unlimited. Allievi ${ }^{77}$ argued that the lack of 'one common origin' and a 'common point of reference' shared together as well as the existing internal ethno-cultural diversities and fragmentations have made it almost impossible to form a 'religious and communitarian organisation for the totality of Muslim immigrants'. As shown in Baumann's (1996) ethnographic study, London Southallian

${ }^{76}$ P. Mandaville, "Reimagining Islam in Diaspora: The Politics of Mediated Community", Gazette, 63 (2001): 169-186; Mandaville, P., "Communication and Diasporic Islam: A Virtual Ummah?" in Karim, K. H. (ed.). The Media of Diaspora, London: Routledge, 2003; see also Bunt, G. R. Islam in the Digital Age: E-Jihad, Online Fatwas and Cyber Islamic Environments. London: Pluto Press, 2003; Bunt, G. R. Muslims: Rewiring the House of Islam, University of North Carolina Press, 2009 on the formation of the cyber religious environment; Bowen, J. R., "Beyond Migration: Islam as a Transnational Public Space", Journal of Ethnic and Migration Studies, 30 (2004): 879-894 on the formation of a transnational Muslim public sphere via the Internet)

${ }^{77} \mathrm{~S}$. Allievi, "Islam in the public space: social networks, media and neo-communities", in Allievi, S. \& Nielsen, J. (eds.), Muslim Networks and Transnational Communities in and across Europe, Leiden: Brill, 2003, 11. 
Muslims have retained their ethnic and sectarian primordial affinities irrespective of their religiosity (or lack thereof).

As explored by Gilliat-Ray (2010), the internal diversity and fragmentation of Muslim communities have something to do with existing Islamic religious sectarian divisions in Britain imported from immigrants' home countries, particularly the Middle East and South Asia. Baskh et al (2008) explain that British Muslim religious diversity resembles the historical and worldwide Muslim community since almost all Islamic sects including the two main branches of Islam, Sunni and Shia and their subgroups, have taken root in this country. The influence of Sunni-Arabo Islam can be seen in several politically radical groups like Hizb ut-Tahrir (the Islamic Liberation Party), Al Muhajiroun (the Emigrants) and the grassroots-oriented Jam'iyat Ihya' Minhaj al-Sunnah (JIMAS) or 'Association to Revive the Way of the Messenger. The Muslim Brotherhood has no official branches open in Europe including Britain (Marechal, 2008) but Gilliat-Ray (2010) insists that its strong influence can be seen in Muslim associations linked to the Middle East such as the Muslim Association of Britain (the MAB). The influence of Sunni-Hanafi South Asian Islamic forms is of course more dominant within British Muslim communities since two thirds of them originally came from the region. This includes Deobandi and Barelwi Maslaqain (sub-schools) and their affiliates such as Tablighi Jamaat and Ahle Sunnah Wal Jamaat. The Shia Muslim groups (e.g. Ithna Ashari and Ismaill) consisting of immigrants from Iran, Iraq, South Asia and East Africa, have also established sectarian religious communities in Britain. ${ }^{78}$

Apart from the major ethno-religious sectarian groupings, many other Muslim immigrants from Somalia (Berns McGown, 1999), Turkey

\footnotetext{
${ }^{78} \mathrm{~N}$. Baksh, Cantle, T., Lempriere, J. \& Kaur, D. Understanding and Appreciating Muslim Diversity: Toward Better Engagement and Participation, Coventry: Institute of Community Cohesion, 2008.
} 
(Kucukcan, 1999) and Bosnia79 have formed their own low profile ethnoreligious communities and separated from the predominantly IndoPakistani or Middle Eastern Muslim organisations. ${ }^{80}$ According to Hussain (2008), the reason behind their preference to be hidden derived from their being smaller in number, having different ethno-religious traditions, avoiding anti-Islam or anti-Muslim hate attacks from natives and having uncertainties about their future settlement in this country. Another reason behind this preference is the strong influence of transnational religious ties with their home countries. Many Muslim institutions like mosques have received a large sum of funds and their religious materials are supplemented from the Muslim countries of the Middle East. ${ }^{81}$

The internal ethnic and sectarian diversity and the fragmentation of Muslim communities in Britain, as Gilliat-Ray (2010) concluded, illustrate the lack of cohesiveness of the Muslim diaspora, which is more or less forged by historical and theological divisions within the worldwide Muslim community. According to Lewis (1994), the phenomenon can be explained by the pattern of fusion and fission in which Muslims tend to unite by leaving aside any ethnic or sectarian differences and fragmentation when small in number; but later disassemble when their numbers increase. Suffice to say that while British society has become multicultural, multifaith and multi-ethnic, Muslim immigrant communities have also become 'multi-Muslim'. ${ }^{82}$

\footnotetext{
${ }^{79}$ L. Kelly, "Bosnian Refugee in Britain: Questioning Community", Sociology, 37 (2003): 35-49.

${ }^{80} \mathrm{H}$. Ansari, The Infidel Within: Muslim in Britain since 1800, London, Hurst and Company, 2004.

${ }^{81} \mathrm{H}$. Ansari, The Infidel Within: Muslim in Britain since 1800, London, Hurst and Company, 2004; Gilliat-Ray, S. Muslims in Britain: An Introduction, Cambridge: Cambridge University Press, 2010.

${ }^{82} \mathrm{~S}$. Vertovec, "Multicultural, Multi-Asian, Multi-Muslim leicester: Dimensions of social complexity, ethnic organization and local government interface", Innovation: The European Journal of Social Science Research, 7 (1994): 259-276.
} 


\section{Integration through the diasporic institutionalisation of Islam}

Similar to other immigrant religious groups in Western countries, the socio-religious integration of Muslim immigrants in Britain, in spite of their being ethnically diverse and divided by various sectarian affiliations, has involved the reproduction of core ethno-religious traditions being influenced by micro and macro local and national structures in the home and host countries. The adoption of the politics of multiculturalism by Western countries, especially Britain, in the last few decades has given opportunities for Muslim immigrants to do so without regard to challenge from the secularised or Christianised culture of the society. The institutionalisation of Islam (and other immigrant religions like Hinduism) has tremendous impact on the transformation and pluralisation of the socio-religious life of Western society in general. ${ }^{83}$ In a nutshell, the diasporic institutionalisation of Islam has provided an ethno-religious integration path for Muslim immigrants alongside the mainstream trajectory of incorporation into secularised Western society. Through this integration path, Muslim immigrants pursue and reproduce their ethno-religious traditions oriented either towards home or host country contexts with different scopes and intensities.

To note, the diasporic institutionalisation of Islam not only describes the ethno-religious integration path of Muslim immigrants but also resembles the essential features of religion, which travels and moves unremittingly wherever people settle and lodge. ${ }^{84}$ In other words, religion is regarded as having societal and individual influences over immi-

${ }^{83}$ For further discussion see S. T. Hunter, (ed.), Islam, Europe's Second Religion: The New Social, Cultural and Political Landscapes, Westport: Prager, 2002; Nielsen, J. S. Muslims in western Europe,Edinburgh: Edinburgh University Press, 2004' Knippenberg, H. (ed.), The Changing Religious Landscape of Europe, Amsterdam: Het Spinhuis, 2005 to name just a few.

${ }^{84}$ T. A. Tweed, Crossing and Dwelling: A Theory of Religion, Cambridge: Harvard University Press, 2006. 
grants while at the same time becoming an object of change, modification and innovation. In the context of Muslims, as Asad (1986) argued, ethno-religious traditions defined as 'discursive traditions' have been continuously forged by the dialectical interaction between sacred texts and social contexts. The development of Islamic civilisation for about fourteen centuries has of course generated diverse ethno-religious traditions across different Muslim ethnic groups worldwide. But this internal Muslim diversity and fragmentation does not necessarily impoverish the role of the fundamental tenets of Islam - grounded in the Qur'an and the Hadith -which have inspired these Islamic 'discursive traditions'. ${ }^{85}$ In other words, there is always a similarity, sameness and conformity in the roots of those diverse ethno-religious traditions regardless of their particular cultural specificity and social structure. ${ }^{86}$

Derived from their religious impulse, Muslim immigrants diligently pursue their ethno-religious traditions, be they diverse in terms of ethnic and sectarian affiliations, by adapting to or adopting the sociopolitical and economic structures of the place they live in. As elaborated by Metcalf (1996), the first stage of diasporic reproduction of ethnoreligious traditions involves both the sacralisation of private and public space, either spatially or non-spatially, and the re-creation of socioreligious institutions in order to pursue and transplant those traditions into a new context. Non-spatial sacralisation is instantiated by the personal discipline of conducting five-daily prayers to a fixed timetable and in whatever place the individual is at the given time. Spatial sacralisation may be limited initially to the private realm such as the construction of a special place in the house designed specifically for praying and the

${ }^{85}$ T.Asad, The Idea of An Anthropology of Islam, Washington: Center for Contemporary Arab Studies, Georgetown University, 1986.

86]. R. Bowen, "Beyond Migration: Islam as a Transnational Public Space", Journal of Ethnic and Migration Studies, 30 (2004): 879-894. 
decoration of living rooms with Islamic calligraphies. Spatial sacralisation would directly encounter the public sphere by building a mosque in a concentrated Muslim neighbourhood, demanding hala/ dietary provision for school meals, requesting exemptions for women to wear headscarves as parts of dress code in schools or work uniforms and asking permission to use a public building, hall or park to hold a religious feast.

In Britain, compared to their co-religionists in other Western European countries like France and Germany, Muslim immigrants and their offspring have enjoyed greater space and opportunity to pursue their ethno-religious traditions and establish socio-religious institutions, which is considered an important step in their integration into British society. ${ }^{87}$ As discussed at length in the first section, with the official declaration of Britain as a 'multicultural country', Muslim immigrants and their offspring have been able to maintain their different ethno-religious cultures, request public accommodation or exemption and recognition for their religious needs and to establish (fairly exclusive) ethno-religious communities without challenging the very idea of the British nationstate. ${ }^{88}$ The British government has treated Islam and Muslims with respect and approval by encouraging them to make a positive contribution to British society without necessarily abandoning their ethnoreligious traditions; these being lessons learnt from Britain's past colonial experience governing Muslim subjects in the Middle East, Africa and Asia. ${ }^{89}$

${ }^{87}$. S.Fetzer \& Soper, J. C. Muslims and the State in Britain, France and Germany, Cambridge: Cambridge University Press, 2005; see also Vertovec, S. \& Peach, C. (eds.). Islam in Europe: The Politics of Religion and Community, Basingstoke: Macmillan, 1997.

${ }^{88} \mathrm{C}$. Joppke, "Multiculturalism and Immigration: A Comparison of the United States, Germany, and Great Britain", Theory and Society, 25 (1996): 449-500; Kivisto, P. Multiculturalism in a Global Society, Oxford: Blackwell, 2002.

89]. S. Nielsen, Muslims in western Europe, Edinburgh: Edinburgh University Press, 2004. 
In current British politics, nonetheless, multiculturalism does not stand alone but is supplemented by integration policy promoting a common sense of belonging and social cohesion amongst millions of British immigrants and their descendants, which in some ways continues to allow Muslims to preserve and reproduce their ethno-religious traditions. ${ }^{90}$ Nevertheless, it is the case that the World Trade Center tragedy in 2001 was followed by a series of terrorist plots and attacks on British soil including the ' $7 / 7^{\prime}$ London bombing, such that the life of Muslim immigrants has been 'under pressure', ${ }^{11}$ with Muslims being targeted by anti-Islam and anti-Muslim hate attacks ${ }^{92}$ and subjected to public suspicion and state securitisation..$^{93}$ Under the new theme of (equality and) diversity, nevertheless, the ethno-religious difference of Islamic traditions is continuously recognised by the state and the public. ${ }^{94}$ Furthermore, Werbner (2009) illustrates the growing confidence of Muslim immigrants and their offspring, through certain Muslim organisations (e.g. the MCB), to engage and articulate their voices in the sociopolitical environments of British society.

Ever since the 1970s, Muslim immigrants have organised themselves by forming local religious and social associations and institutions

${ }^{90}$ N.Meer \& Modood, T., "The Multicultural State We're In: Muslims, 'Multiculture' and the 'Civic Re-balancing' of British Multiculturalism", Political Studies, 57 (2009): 473-497; Vertovec, S. \& Wassendorf, S., "Introduction: Assessing the Backlash against Multiculturalism in Europe", in Vertovec, S. \& Wassendorf, S. (eds.), The Multiculturalism Backlash: European Discourses, Policies and Practices, London: Routldge, 2010.

${ }^{91}$ T. Abbas, "British South Asian Muslims: before and after September 11", in Abbas, T. (ed.). Muslim Britain: Community Under Presure, London: Zed Books, 2005.

${ }^{92}$ C.Allen, "From Race to Religion: the New Face of Discrimination", in abbas, T. (ed.). Muslim Britain: Community Under Pressure, London: Zed Books, 2005; Allen, C. Islamophobia, Surrey, Burlington, Ashgate, 2010.

93].Cesari, Securitisation of Islam in Europe. In: CESARI, J. (ed.) Muslims in the West after 9/ 11: Religion, Politics and Law, Oxon: Routledge, 2010.

${ }^{94} \mathrm{~T}$. Faist, "Diversity - a new mode of incorporation?", Ethnic and Racial Studies, 32 (2009): 171-90; Vertovec, S., "Towards post-multiculturalism? Changing communities, conditions and contexts of diversity", International Social Science Journal, 61 (2010): 83-95. 
across towns and cities in Britain. ${ }^{95}$ Based on his ethnographic study among South Asian Muslims in Bradford, Lewis (1994) delineated the institutionalisation of Islam in terms of its refusal to remain invisible to the public through the establishment of Islamic socio-religious institutions and active socio-political engagement with the host society. This has included the creation of mosques, religious and ethnic communal associations, supplementary ethno-religious schools (e.g. similar to Sunday schools organised by the Church of England), distinct economic and commercial activities serving ethno-religious needs and active engagement with local councils concerning Muslim affairs like the provision of halal food in schools. ${ }^{96}$

An integral part of the process is the socio-religious empowerment of women. It has been argued that women have played a prominent role as cultural actors in the reproduction of ethno-religious traditions within immigrant communities. For (Indo-Pakistani) Muslims in Britain, the arrival of wives (and children) in the 1970s, enabling family reunions, is regarded as the starting point for the institutionalisation of Islam. ${ }^{97}$ Muslim women have espoused their socio-religious roles, starting with the inception of informal Qur'anic study groups (halaqat), then formalised as divisions of mosque organisations, which allowed them (housewives) spaces to gather and discuss various religious issues relating to their families and communities. These Muslim women's groups later evolved into independent organisations focused on charitable ac-

${ }^{95} \mathrm{~S}$. Vertovec, "Towards post-multiculturalism? Changing communities, conditions and contexts of diversity", International Social Science Journal, 61 (2010): 83-95.

${ }^{96}$ See also S. Vertovec, "Multicultural, Multi-Asian, Multi-Muslim leicester: Dimensions of social complexity, ethnic organization and local government interface", Innovation: The European Journal of Social Science Research, 7 (1994): 259-276 among South Asians in Leicester.

${ }^{97}$ See P. Lewis, Islamic Britain: Religion, Politics and Identity among British Muslim: Bradford in the 1990s, London: I.B. Taurus, 1994; Ansari, H. The Infidel Within: Muslim in Britain since 1800, London, Hurst and Company, 2004. 
tivities (e.g. Al-Masoom in Manchester, ibid) and/or various civic-political engagements combating gender discrimination within and without Muslim communities (e.g. An-Nisa Society in London). ${ }^{98}$ As noted by Ansari, ${ }^{99}$ immigration has positively changed the socio-religious status of Muslim women by strengthening their roles both in the family and in public and communal activities.

Importantly, these Muslim immigrant women have taken a stance against the shackles of patriarchy in their ethno-religious communities by promoting gender equality derived from the primary Islamic authority. The stance has gained wider support particularly from second generation Muslim women. Having been raised and educated in Britain, they demand similar rights to their brothers in terms of having opportunities both to pursue their education, follow a professional career and participate in religious learning circles and activities. ${ }^{100}$

This critical stage in the diasporic institutionalisation of Islam is an important part of the ethno-religious integration path of Muslim immigrants and is illustrated in the efforts to gain recognition in the British public sphere, which, despite being culturally and institutionally founded on Christian tradition, has been significantly secularised since the middle of the twentieth century. ${ }^{101}$ As Fetzer and Soper note, nonetheless, Britain has in fact adopted a pragmatic policy of religious pluralism amid

${ }^{98}$ See S. Gilliat-Ray, Muslims in Britain: An Introduction, Cambridge: Cambridge University Press, 2010.

${ }^{99} \mathrm{H}$. Ansari, The Infidel Within: Muslim in Britain since 1800, London, Hurst and Company, 2004.

${ }^{100}$ See J. Jacobson, Islam in Transition: Religion and Identity among British Pakistani Youth, London: Routledge, 1998.

${ }^{101}$ See C. G. Brown, Religion and Society in Twentieth-Century Britain, Harlow: Pearson Education Limited, 2006; Brown, C. G. The Death of Christian Britain: Understanding secularisation 1800-2000, Oxon: Routledge, 2009; Mcleod, H. The Religious Crisis of the 1960s, Oxford: Oxford University Press, 2007; Green, S. J. D. The Passing of Protestant England: Secularisation and Social Change c. 1920-1960, Cambridge: Cambridge University Press, 2011. 
the privileged status enjoyed by the Anglican Church as the official religious institution. ${ }^{102}$ It allows adherents of minority religions (e.g. Jews, Sikhs, Hindus and Muslims) to exercise their religious rights freely in terms of practicing faith and building religious social institutions protected by law. ${ }^{103}$

The problem, nonetheless, is derived from the prevalence of secularism in British society. The predominance of the secular worldview with its strict division between public and private spheres has shaped the preference of state officials and policy makers in this country to disregard religious issues as an important matter in the public sphere. ${ }^{104}$ Britain does, however, have an anti-blasphemy law protecting the sacredness of the Christian faith only. Immigrant minorities are commonly defined in terms of race and are protected from discrimination under the Race Relations Act, which was extended to include ethno-religious groups like the Jews and Sikhs but not Muslims. ${ }^{105}$ The quest by Muslims for state

102]. S. Fetzer \& Soper, J. C. Muslims and the State in Britain, France and Germany, Cambridge: Cambridge University Press, 2005.

${ }^{103}$ See also J. S. Nielsen, Muslims in western Europe, Edinburgh: Edinburgh University Press, 2004.

104]. S. Fetzer \& Soper, J. C. Muslims and the State in Britain, France and Germany, Cambridge: Cambridge University Press, 2005; see also Modood, T. Multicultural Politics: Racism, Ethnicity and Muslims in Britain,Edinburgh: Edinburgh University Press, 2005; Modood, T., "British Muslims and the politics of multiculturalism", in Modood, T., Triandafyllidou, A. \& Zapata-Barrero, R. (eds.), Multiculturalism, Muslims and Citizenship: A European Approach, London, New York: Routledge, 2006.

${ }^{105}$ It was argued that Muslims-qua-Muslims had been left legally unprotected from discrimination; that Islam was open to incitement to hatred (i.e. the Satanic Verses affair) and its religious demands were only minimally accommodated (i.e. State Funding for Muslim schools) (see T. Modood, Multicultural Politics: Racism, Ethnicity and Muslims in Britain, Edinburgh: Edinburgh University Press, 2005; Modood, T., "British Muslims and the politics of multiculturalism", in Modood, T., Triandafyllidou, A. \& Zapata-Barrero, R. (eds.), Multiculturalism, Muslims and Citizenship: A European Approach,London, New York: Routledge, 2006; Allen, C., "From Race to Religion: the New Face of Discrimination", in abbas, T. (ed.). Muslim Britain: Community Under Pressure,London: Zed Books, 2005; Modood, T. \& Kartoryano, R., "Secularism and the Accomodation of Muslim Identities", in Raymnod, G. G. \& Modood, T. (eds.), The Construction of Minority Identity in France and Britain, Basingstoke, Hampshire and New York: Palgrave Macmillan, 2007. 
protection from discrimination on the basis of their religion was eventually accommodated in the 2006 Racial and Religious Hatred Act.

The marginal position of Muslim immigrants in Britain has encouraged them to establish a unified Muslim body, which is able to formally represent all Muslims and negotiate their political demands vis-à-vis the British state. Ansari ${ }^{106}$ explored the ways in which Muslim immigrants began to organise themselves around informal and kinship-based communal associations and later around mosques at regional levels with the Council of Mosques (COM) established to respond to the 1985 Swann Report on multicultural education reform, the UK Action Committee of Islamic Affairs (UKACIA) to mobilise Muslims in the wake of the Salman Rushdie Satanic Verses affair, the politically active Iranianbacked 'Muslim Parliament' led by Kalim Siddiqi and the Muslim Council of Britain (MCB) formed in May 1996. The MCB has been given a significant role to play as an umbrella organisation and to represent and articulate the political aspirations of the whole Muslim community at a national level similar to The Board of Deputies of British Jews. The council now claims to have about 500 affiliates of local and national Muslim organisations, mosques, Islamic charities and schools (www.mcb.org.uk, n.d).

\section{Concluding remark}

Throughout the article, I argue that the integration of Muslim immigrants in Britain has been occurred in the complex processes, which are influenced, on the one hand, by British multiculturalism and the secularisation of British society; and on the other by the institutionalisation of Islam via the reproduction of ethno-religious traditions in the immi-

${ }^{106} \mathrm{H}$. Ansari, The Infidel Within: Muslim in Britain since 1800, London, Hurst and Company, 2004. 
grant land. The accommodation and recognition of the ethnic, racial and religious differences of immigrants under the British Multiculturalism and the subtle secularisation/desecularisation of the British society have opened the doors for them to pursue and transplant their ethno-religious tradition - imported from the home country - the this country. Despite the ongoing internal diversity and fragmentation, Muslim immigrants in Britain have established various socio-religious institutions and associations, which are not only aimed to serve their own interests yet also representing them to the British state and public respectively. In addition to these achievements, integration has a positive impact on female socio-religious roles breaking away from the patriarchal system brought in from the home country into minority British Muslim communities. To sum up, the complex integration of Muslim immigrants in Britain has illustrated the enduring role of religious in the context of immigrants that is shaping their integration mode yet institutionally and socially modified to adapt the structural fabric of the host society.

\section{Bibliography}

Abbas, T., "British South Asian Muslims: before and after September 11", in Abbas, T. (ed.). Muslim Britain: Community Under Presure. London: Zed Books, 2005.

Abbas, T., "Introduction: Islamic Political Radicalism in Western Europe", in abbas, T. (ed.). Islamic Political Radicalism: A European Perspective. Edinbrugh: Edinbrugh University Press, 2007.

Ahmed, A. S. Islam Under Siege. Cambridge, Polity Press, 2003.

Allen, C., "From Race to Religion: the New Face of Discrimination", in abbas, T. (ed.). Muslim Britain: Community Under Pressure. London: Zed Books, 2005.

Allen, C. Islamophobia. Surrey, Burlington, Ashgate, 2010. 
Allievi, S., "Islam in the public space: social networks, media and neocommunities", in Allievi, S. \& Nielsen, J. (eds.). Muslim Networks and Transnational Communities in and across Europe. Leiden: Brill, 2003.

Ansari, $\mathrm{H}$. The Infidel Within: Muslim in Britain since 1800. London, Hurst and Company, 2004.

Anthias, F., "Beyond Feminism and Multiculturalism: Locating Difference and the Politics of Location", Women's Studies International Forum, 25, (2002): 275-286.

Anthias, F. \& yuval-davis, N. Racialized Boundaries: Race, Nation, Gender, Colour and Class and the Anti-racist Struggle. London, Routledge, 1993.

Asad, T. The Idea of An Anthropology of Islam. Washington: Center for Contemporary Arab Studies, Georgetown University, 1986.

Back, L., Keith, M., Khan, A., Shukra, K. \& Solomos, J. New labour's White Heart, "Politics of Multiculturalism and the Return of Assimilation", the Political Quaterly, 73 (2002a): 445-454.

Back, L., Keith, M., Khan, A., Shukra, K. \& Solomos, J., "The Return of Assimilationism: Race, Multiculturalism and New Labour", Sociological Research Online [Online], (2002b).Available: http:// www.socresonline.org.uk/7/2/back.html.

Bagguley, P. \& Hussain, Y. Riotous Citizens: Ethnic Conflict in Multicultural Britain. London, Ashgate, 2008.

Baksh, N., Cantle, T., Lempriere, J. \& Kaur, D. Understanding and Appreciating Muslim Diversity: Toward Better Engagement and Participation. Coventry: Institute of Community Cohesion, 2008. 
Banting, K. \& Kymlicka, W. Multiculturalism and the Welfare State: Recognition and Redistribution in Contemporary Democracies. Oxford: Oxford University Press, 2006.

Barry, B. Culture and Equality: An Egalitarian Critique of Multiculturalism. Cambridge: Polity, 2001.

Baumann, G. Contesting Culture: Discourse of identity in multi-ethnic London. Cambridge: Cambridge University Press, 1996.

Berns-Mcgown, R. Muslims in the Diaspora: the Somali Communities of London and Toronto. Toronto: University of Toronto Press, 1999. Bluck, R., Gilliat-Ray, S., Graham, D. J., Singh, G. \& Zavos, J. Judaism, Sikhism, "Islam, Hinduism and Buddhism: post-war settlements", in Woodhead, L. \& Catto, R. (eds.). Religion and Change in Modern Britain. Abingdon: Routledge, 2012.

Bowen, J. R., "Beyond Migration: Islam as a Transnational Public Space", Journal of Ethnic and Migration Studies, 30 (2004): 879-894.

Brown, C. G. Religion and Society in Twentieth-Century Britain. Harlow: Pearson Education Limited, 2006.

Brown, C. G. The Death of Christian Britain: Understanding secularisation 1800-2000. Oxon: Routledge, 2009.

Brown, M. S., "Religion and Economic Activity in the South Asian Population", Ethnic and Racial Studies, 23 (2000): 1035-61.

Bruce, S. God is Dead: Secularization in the West. Oxford: Blackwell, 2002.

Bruce, S. Secularization: In Defence of Unfashionable Theory. Oxford: Oxford University Press, 2011.

Bunt, G. R. Virtually Islamic: computer-mediated communication and cyber Islamic environments. Cardiff: University of Wales Press, 2000. 
Bunt, G. R. Islam in the Digital Age: E-Jihad, Online Fatwas and Cyber Islamic Environments. London: Pluto Press, 2003.

Bunt, G. R. Muslims: Rewiring the House of Islam. University of North Carolina Press, 2009.

Cantle, T. Community Cohesion: A Report of the Independent Review Team. London: HMSO, 2001.

Cesari, J. Securitisation of Islam in Europe. In: CESARI, J. (ed.) Muslims in the West after 9/11: Religion, Politics and Law. Oxon: Routledge, 2010.

Dahya, Z. The Nature of Pakistani Ethnicity in Industrial Cities in Britain. In: cohen, A. (ed.) Urban Ethnicity. London: Tavistock, 1975.

Dasetto, F., "Muslims in Western Europe: Sociohistorical Developments and Trends", in Tsugitaka, S. (ed.). Muslim Societies: Historical and Comparative Aspects. London: RoutledgeCurzon, 2004.

Davie, G., "Believing without Belonging: Is This the Future of Religion in Britain", Social Compass, 37 (1990): 455-469.

Davie, G. Religion in Britain since 1945: Believing Without Belonging. Oxford: Blackwel, 1994.

Davie, G., "Religion in Modern Britain: Changing Sociological Assumptions", Sociology, 34 (2000): 113-28.

Davie, G., "Vicarious Religion: A Methodological Challenge", in Ammerman, N. T. (ed.). Eeveryday Religion: Observing Modern Religious Lives. Oxford: Oxford University Press, 2007.

Dinham, A. \& Jackson, R., "Religion, Welfare and Education", in Woodhead, L. \& Catto, R. (eds.). Religion and Change in Modern Britain. Abingdon: Routledge, 2012. 
Dinham, A. \& Lowndes, V., "Faith and the Public Realm", in Dinham, A., Furbey, R. \& Lowndes, V. (eds.). Faith in the Public Realm: Controversies, Policies and Practices. Bristol: The Policy Press, 2009.

Esposito, J. L., "The Muslim Diaspora and the Islamic World", in Hunter, S. T. (ed.). Islam Europe's Second Religion: The New Social, Cultural and Political Landscape. London: Praeger, 2002.

Faist, T., "Diversity - a new mode of incorporation?", Ethnic and Racial Studies, 32 (2009): 171-90.

Fetzer, J. S. \& Soper, J. C. Muslims and the State in Britain, France and Germany. Cambridge: Cambridge University Press, 2005.

Ganiel, G. \& Jones, P., "Religion, Politics and Law", in Woodhead, L. \& Catto, R. (eds.). Religion and Change in Modern Britain. Abingdon: Routledge, 2012.

Gest, J. Apart: Alienated and Eangaged Muslims in the West. London: Hurst and Co., 2010.

Gilliat-Ray, S. Muslims in Britain: An Introduction. Cambridge: Cambridge University Press, 2010.

Green, S. J. D. The Passing of Protestant England: Secularisation and Social Change c. 1920-1960. Cambridge: Cambridge University Press, 2011.

Grillo, R., "Islam and Transnationalism", Journal of Ethnic and Migration Studies, 30 (2004): 861-879.

Grillo, R., "British and others: Fron 'Race' to 'Faith'", in Vertovec, S. \& Wassendorf, S. (eds.). The Multiculturalism Backlash: European Discourses, Policies and Practices. London: Routledge, 2010.

Halliday, F. Britain's first Muslims: portrait of an Arab community. London: IB. Tauris, 2010. 
Heelas, P., "The Spiritual Revolution: From 'Religion' to 'Spritituality"' in Woodhead, L., Fletcher, P., Kawanami, H. \& Smith, D. (eds.). Religions in the modern World: Traditions and Transformations. London, New York: Routledge, 2002.

Heelas, P. \& Woodhead, L. The Spiritual Revolution: Why Religion is Giving Way to Spirituality. London: John Wiley and Son, 2005.

Hesse, B., "Introduction: Un/Settled Multiculturalisms", in Hesse, B. (ed.) Un/Settled Multiculturalisms: Diasporas, Entanglements and Trasnruptions. London: Zed Book, 2000.

Hopkins, P. \& Gale, R. (eds.). Muslims in Britain: Race, Place and identities. Edinburgh: Edinburgh University Press, 2009.

Hunter, S. T. (ed.). Islam, Europe's Second Religion: The New Social, Cultural and Political Landscapes, Westport: Prager, 2002

Hussain, S. Muslims on the Map: A National Survey of Social Trends in Britain. London: Tauris Academic Studies, 2008.

Jacobson, J. Islam in Transition: Religion and Identity among British Pakistani Youth. London: Routledge, 1998.

Johnsen, S., "Case Study 6: the Role of Faith-based Organization in service provision for homeless people", in Woodhead, L. \& Catto, R. (eds.). Religion and Change in Modern Britain. Abingdon: Routledge. 2012.

Joppke, C., "Multiculturalism and Immigration: A Comparison of the United States, Germany, and Great Britain", Theory and Society, 25 (1996): 449-500.

Joppke, C., "How Immigration is Changing Citizenship: A Comparative View", Ethnic and Racial Studies, 22 (1999a): 629-652.

Joppke, C. Immigrantion and the Nation-State. Oxford: Oxford University Press, 1999b. 
Joppke, C., "The Retreat Of Multiculturalism in The Liberal State: Theory And Policy", The British Journal of Sociology, 55 (2004): 237-257. Joppke, C. \& Luke, S., "Introduction: Multicultural Questions", in Joppke, C. \& Luke, S. (eds.). Multicultural Questions. Oxford: Oxford University Press, 2002.

Kelly, L., "Bosnian Refugee in Britain: Questioning Community", Sociology, 37 (2003): 35-49.

Kerbaj, R., "Muslim population 'rising 10 times faster than rest of society'", Times Online, 2009.

Kivisto, P. Multiculturalism in a Global Society. Oxford: Blackwell, 2002.

Kivisto, P. \& Faist, T. 2007. Citizenship: Discourse, Theory, and Transnational Prospects, London, Blackwell.

Knippenberg, $\mathrm{H}$. (ed.). The Changing Religious Landscape of Europe. Amsterdam: Het Spinhuis, 2005.

Koopmans, R. \& Statham, P., "Challenging the Liberal Nation-State? Postnationalism, Multiculturalism, and the Collective Claims Making of Migrants and Ethnic Minorities in Britain and Germany", The Americal Journal of Sociology, 105 (1999): 652-696.

Kücükcan, T. Politics of Ethnicity, Identity and Religion: Turkish Muslims in Britain. Aldershot: Ashgate, 1999.

Kundnani, A., "The Death of Multiculturalism", Race and Class, 43 (2002): 67-72.

Kymlicka, W. Multicultural Citizenship: A Liberal Theory of Minority Rights.

Oxford: Oxford University Press, 1995.

Lewis, P. Islamic Britain: Religion, Politics and Identity among British Muslim: Bradford in the 1990s. London: I.B. Taurus, 1994. 
Mandaville, P., "Reimagining Islam in Diaspora: The Politics of Mediated Community", Gazette, 63 (2001): 169-186.

Mandaville, P., "Communication and Diasporic Islam: A Virtual Ummah?" in Karim, K. H. (ed.). The Media of Diaspora. London: Routledge, 2003.

Marechal, B., Allievi, S., Dassetto, F. \& Nielsen, J. (eds.). Muslims in the Enlarged Europe: Religion and Society. Leiden: Brill, 2003.

Matar, N. I. Islam in Britain 1558-1685. Cambridge: Cambridge University Press, 1998.

Mcleod, H. The Religious Crisis of the 1960s. Oxford: Oxford University Press, 2007.

Mcloughlin, S. N. \& Abbas, T., "United Kingdom", in Nielsen, J. S., AkgoNuL, S., Alibasici, A., Mareìchal, B. \& Moe, C. (eds.). Yearbook of Muslims in Europe. Leiden: Brill. 2010.

Mcphee, S., "Muslim Identity: The European Context", Sussex Migration Working Paper No: 34. Sussex: Sussex Centre for Migration Studies, 2005.

Meer, N. Citizenship, Identity and the Politics of Multiculturalism: The Rise of Muslim Consciousness. Basingstoke: Palgrave Macmillan, 2010.

Meer, N. \& Modood, T., "The Multicultural State We're In: Muslims, 'Multiculture' and the 'Civic Re-balancing' of British Multiculturalism", Political Studies, 57 (2009): 473-497.

Modood, T., "Introduction: the Politics of Multiculturalism in the New Europe", in Modood, T. \& Werbner, P. (eds.). The Politics of Multiculturalism in the New Europe: Racism, identity and Community. London: Zed Books, 1997. 
Modood, T. Multicultural Politics: Racism, Ethnicity and Muslims in Britain. Edinburgh: Edinburgh University Press, 2005.

Modood, T., "British Muslims and the politics of multiculturalism", in Modood, T., Triandafyllidou, A. \& Zapata-Barrero, R. (eds.). Multiculturalism, Muslims and Citizenship: A European Approach. London, New York: Routledge, 2006.

Modood, T., Berthoud, R., Lakey, J., Nazroo, J., Smith, P., Virdee, S. \& Beishon, S. (eds.) Ethnic Minorities in Britain: Disadvantage and Diversity. London: Policy Studies Institute, 1997.

Modood, T. \& Kartoryano, R., "Secularism and the Accomodation of Muslim Identities", in Raymnod, G. G. \& Modood, T. (eds.). The Construction of Minority Identity in France and Britain. Basingstoke, Hampshire and New York: Palgrave Macmillan, 2007.

Moghissi, H. (ed.) Muslim Diaspora: Gender, culture and identity. Oxon: Routledge, 2006.

Moghissi, H., "Introduction", in Moghissi, H. (ed.). Muslim Diaspora in the West: Negotiating Gender, Home and Belonging. Farnham: Ashgate, 2010.

Moghissi, H., Rahnema, S. \& Goodman, M. J. Diaspora by Design: Muslim Immigrants in Canada and Beyond. Torronto, Buffalo, London: The University of Torronto Press, 2009.

Morris, R. M. Church and State in 21st Century Britain. Basingstoke Hampshire, New York: Palgrave Macmillan, 2009.

Nielsen, J. S. Muslims in western Europe. Edinburgh: Edinburgh University Press, 2004.

Ons. Census 2001: Key Statistics for Local Authorities in England and Wales, 2003. 
Ons. Religion in England and Wales 2012. Available: http:// www.ons.gov.uk/ons/rel/census/2011-census/key-statistics-for-local-authorities-in-england-and-wales/rpt-religion.html.

Parekh, B. Rethinking Multiculturalism. Basingstoke: Palgrave Macmillan, 2000.

Peach, C., "Britian's Muslim Population: an Overview", in Abbas, T. (ed.). Muslim Britian: Coomunity Under Presure. London: Zed Books, 2005a.

Peach, C., "The United Kingdom: A major transfromation of the religious landscape", in Knippenberg, H. (ed.). The Changing Religious Landscape of Europe. Amsterdam: Het Spinhuis, 2005b.

Peach, C., "Muslims in the 2001 Census of England and Wales: Gender and economic disadvantage", Ethnic and Racial Studies, 29 (2006a): 629-655.

Pearce, B., "Case Study 2: the Inter Faith Network and the Development of Inter Faith Relation in Britain", in Woodhead, L. \& Catto, R. (eds.) Religion and Change in Modern Britain. Abingdon: Routledge, 2012.

Pew. The Future of the Global Muslim Population: Projections for 20102030. Washinton: Pew Research Center's Forum on Religion and Public Life, 2011.

Philips, D., "Parallel lives? Challenging discourses of British Muslim selfsegregation", Environment and Planning Deevelopment, 24 (2006): $25-40$.

Taylor, C., "The Politics of Multiculturalism", in Gutman, A. (ed.). Multiculturalism: Examining the Politics of Recognition. Princeton, New Jersey: Princeton University Press, 1994. 
Trust, R. Islamophobia: a Challenge fo Us All. London: Runnymede Trust, 1997.

Tweed, T. A. Crossing and Dwelling: A Theory of Religion. Cambridge: Harvard University Press, 2006.

Vertovec, S., "Multicultural, Multi-Asian, Multi-Muslim Leicester: Dimensions of social complexity, ethnic organization and local government interface", Innovation: The European Journal of Social Science Research, 7 (1994): 259-276.

Vertovec, S., "Towards post-multiculturalism? Changing communities, conditions and contexts of diversity", International Social Science Journal, 61 (2010): 83-95.

Vertovec, S. \& Peach, C. (eds.). Islam in Europe: The Politics of Religion and Community. Basingstoke: Macmillan, 1997.

Vertovec, S. \& Wassendorf, S., "Introduction: Assessing the Backlash against Multiculturalism in Europe", in Vertovec, S. \& Wassendorf, S. (eds.) The Multiculturalism Backlash: European Discourses, Policies and Practices. London: Routldge. 2010.

Voas, D. \& Crockett, A., "Religion in Britain: Neither Believing nor Belonging", Sociology, 39 (2005): 11-28.

Woodhead, L., "Introduction", in Woodhead, L. \& Catto, R. (eds.). Religion and Change in Modern Britain. Abingdon: Routledge, 2012. 